\title{
ALLERGIC CONTACT DERMATITIS FROM FORMALDEHYDE EXPOSURE
}

\author{
Maya Lyapina ${ }^{1}$, Angelina Kisselova-Yaneva ${ }^{2}$, Assya Krasteva ${ }^{2}$, Mariana Tzekova \\ -Yaneva ${ }^{2}$, Maria Dencheva-Garova ${ }^{2}$ \\ 1) Department of Hygiene, Medical Ecology and Nutrition, Medical Faculty, \\ 2) Department of Oral and Image Diagnostic, Faculty of Dental Medicine, \\ Medical University, Sofia,Bulgaria
}

\begin{abstract}
Formaldehyde is a ubiquitous chemical agent, a part of our outdoor and indoor working and residential environment. Healthcare workers in difficult occupations are among the most affected by formaldehyde exposure. Formaldehyde is an ingredient of some dental materials. Formaldehyde is well-known mucous membrane irritant and a primary skin sensitizing agent associated with both contact dermatitis (Type IV allergy), and immediate, anaphylactic reactions (Type I allergy). Inhalation exposure to formaldehyde was identified as a potential cause of asthma. Quite a few investigations are available concerning health issues for dental students following formaldehyde exposure. Such studies would be beneficial for early diagnosis of hypersensitivity, adequate prophylactic, risk assessment and management of their work.
\end{abstract}

Key words: formaldehyde, allergic contact dermatitis, occupational exposure, dental materials, healthcare workers

Formaldehyde CAS No. 50-00-0

Formaldehyde is a ubiquitous chemical agent, a part of our general outdoor environment, as well as in our indoor working and residential environment. It is believed that exposed to formaldehyde is the whole civilized population.

\section{Properties}

Formaldehyde is the simplest aldehyde. It exists at room temperature as a nearly colorless gas with a pungent, suffocating odor (43). Commercially, formaldehyde is most often available as $30 \%$ to $50 \%$ (by weight) aqueous solutions of the hydrated form, which is commonly referred to as formalin. In the absence of stabilizers, formaldehyde in solution oxidizes slowly to form formic acid and polymerizes to form oligomers, including paraformaldehyde, a polymer with 8 to 100 units of formaldehyde (44).

\section{Environmental exposure}

Because of its high water solubility formaldehyde is contained in rain water, surface and ground waters, and consequently, in soil and foods (63). The main sources being atmospheric air, tobacco smoke, use of cosmetic products and detergents, and in less extend - water and food consumption $(11,81)$. It is released into the atmosphere through fumes from automobile exhausts without catalytic convertors and by manufacturing facilities that burn fossil fuels in usual concentration about 1-10 ppb. Uncontrolled forest fires and the open burning of waste also give off formaldehyde. It is believed that the daily exposure from atmospheric air is up to $0.1 \mathrm{mg}(35,43,44)$.

According to the WHO industrial emissions could appear at each step of production, use, transportation, or deposition of formaldehyde-containing products. Formaldehyde emissions are detected from various industries - energy industry, wood and paper product industries, textile production and finishing, chemical industry, incinerators etc. (83).

\section{Use and occupational exposure}

One of the most important applications of formaldehyde is in production of formaldehyde-containing resins - melamine formaldehyde, urea-formaldehyde, phenol formaldehyde, carbamide formaldehyde etc. Over 60 percent of urea- formaldehyde resin is used as a binder in plywood and particleboard production (79). The textile industry uses formaldehyde-containing resins for fire retardation, increased water repellency, stiffness, and wrinkle-resistance in fabric finishing. Paper products treated with formaldehyde include paper bags, waxed paper, paper towels, and disposable sanitary products and are widely used in our living and working environment. It is also used in foundries, dye and ink producing industries and many other chemicalbased industries. When formaldehyde is present in disinfectants, preservatives, and embalming fluid, worker exposure can occur. Laboratories hospitals, dental facilities, and veterinary settings may make use of formaldehyde. Hospitals use it as a disinfectant and deodorizer. Formaldehyde is an ingredient of dental materials - rootcanal-filling materials, formocresol, sealers and cements, polymers etc. In dental practice common is the concomitant exposure with glutaraldehyde. Highest incidence of occupational exposure is documented in the listed above 
industries $(15,21,22,32,37,39,52,71)$.

\section{Adsorption, distribution, and metabolism}

Exogenous formaldehyde enters the body through inhalation, ingestion and skin absorption. Because formaldehyde is so soluble it is being quickly absorbed by the respiratory and the gastrointestinal tracts. Near $100 \%$ absorption of formaldehyde vapour from the nasal mucosa, trachea and bronchi is likely in humans. Dermal contact is one of the major routes of exposure to formaldehyde, but it is poorly absorbed following dermal application. Nevertheless, a number of factors affect skin absorption of formaldehyde existing dermatitis or acne and/or if the skin is broken or irritated, absorption is increased. High humidity of the air and the area of skin exposed also affect skin absorption of formaldehyde (63). Absorption appears to be limited to cell layers immediately adjacent to the point of contact. Evidence for toxic effects at distant sites is less consistent.

Formaldehyde is rapidly metabolized at the initial site of contact to formate by the enzyme formaldehyde dehydrogenase. Due to rapid metabolism, very little formaldehyde enters the blood stream of humans or animals exposed to formaldehyde as an intact molecule. The distribution of the intact formaldehyde molecule to other more distant organs is not likely, except from exposure to high concentrations.

Inhalation of formaldehyde leads to the formation of DNA-protein cross-links, DNA single-strand breaks, chromosomal aberrations, sister chromatid exchange and gene mutation in human cells in vitro. This is probably the mechanism of the carcinogenic, mutagenic and sensitizing action of formaldehyde $(31,40,63)$.

Importantly, each tissue has an endogenous rate of formaldehyde production due to various pathways involved in single carbon metabolism. Formaldehyde is an essential byproduct in the synthesis of purines, thymidine and some amino acids. Also, it is a metabolite product of some amino acids, drugs, food additives, chemical agents etc. (44). The concentration of endogenous formaldehyde in human blood is about $2-3 \mathrm{mg} / \mathrm{L}$; similar concentrations are found in the blood of monkeys and rats $(\mathbf{1 6 , 4 0 )}$.

\section{Toxic and immunotoxic effects}

Studies indicate that tissue damage and immunotoxic effects following formaldehyde exposure occurs primarily at the portals-of-entry - mainly upper respiratory tract. Consequently, the most likely proximal targets of formaldehyde immunotoxic action are the immune cells in the bronchial and nasal associated lymphoid tissue (BALT and NALT). Most BALT and NALT cells belong to the arm of the immune system referred to as the innate immune system and play a significant role as a first line defense protecting the host in case of tissue damage, from biological agents, apoptotic cells and the harmful effects of environmental insults. The interactions between different BALT and NALT cell populations are complex and complicated, mediated through cytokines, chemokines, growth factors, interactions with endothelial adhesion molecules, etc. The mediators listed above regulate the traffic and recruitment of innate, "nonspecific" and the highly "specific", adaptive immune cells. Due to the migration of these cells through the bloodstream to lymph nodes, spleen, liver and other immune structures, a systematic manifestation of adverse health effects in exposure to toxic agents is possible (20 a.).

The most important adverse health effects resulting from formaldehyde exposure include respiratory tract irritation and increased incidence of infectious diseases, sensitization, mutagenic and carcinogenic action (10).

Well documented is the irritant action of formaldehyde on eyes (watery, itchy eyes), upper respiratory tract (itchy, runny, or stuffy nose, sinus fullness, dry or sore throat) and skin (irritation and dermatitis) $(1,27,56,58,77,78,84)$. Its toxic effects on the respiratory tract include inflammation, alteration of mucociliary clearance $(6,41)$, hyperplastic and methaplastic $<5 \mathrm{~B} 0$ ?;0AB $8 \mathrm{G}=8$ alterations $(7,12,68)$.

On the basis of the listed morphological and functional alterations of nasal and upper respiratory tract mucosa and increased susceptibility to upper respiratory tract infections a suppression of neutrophil respiratory burst activity (NRBA) was suggested. This is discussed as one of the possible immunotoxic effects of formaldehyde.

Krzyzanowski et al. (1990) established a correlation between indoor formaldehyde exposure (in concentration above $60 \mathrm{ppb}$ ) and increased incidence of chronic bronchitis among children as well as among elderly inhabitants (55).

In a previous study we observed a statistically significant predominance of subjective symptoms and objective clinical findings of chronic upper respiratory tract inflammation, as well as decreased resistance to infections within the group of workers occupationally exposed to formaldehyde if compared with unexposed control group, as well as significantly lower spontaneous NRBA in the group of exposed workers with history and clinical findings for frequent and long lasting relapses of upper respiratory tract chronic inflammation if compared with the healthy controls as well as if compared with the group of exposed workers with rare and short acute inflammations of the upper respiratory tract or without any inflammations.

The observed decrease of spontaneous NRBA could be due to formaldehyde exposure and individual susceptibility. The obtained results suggest that functional changes in polymorphonuclear neutrophil granulocytes could serve as an early indicator of an impact of formaldehyde on NRBA. (59).

Alterations of pulmonary function include decrease in pulmonary ventilation and forced vital capacity values, obstruction in the small airways (8). Epidemiological studies carried out among children and occupationally unexposed to formaldehyde population established a relationship between environmental exposure to formaldehyde and clinical manifestation of asthma and sensitization to common allergens 
$(17,18,24,25,84)$. No significant data were available to confirm relationship between formaldehyde exposure and $\mathrm{IgE}$ mediated sensitization $(26,64)$. Results from our previous studies also does not support the role of $\mathrm{Ig}$ - mediated sensitization in occupational exposure to low concentration of formaldehyde (2). Also, we established a significantly increased serum IgA levels among the group of occupationally exposed to formaldehyde with history and clinical findings for chronic inflammatory disorders of upper respiratory tract - chronic rhino-pharyngitis and bronchitis. We suggest that the increased $\operatorname{IgA}$ levels reflects a compensatory response of mucosal immune system (3).

Haemoxic effects of formaldehyde have been discussed in some studies. In our study a statistically significant negative correlation between the duration of occupational exposure to formaldehyde and erythrocyte count and hematocrite level was established. The results could suggest toxic action of formaldehyde on bone marrow haematopoesis (59).

Also, we established a statistically significant relative risk for manifestation of subjective cardiac symptoms and gastrointestinal tract diseases among occupationally exposed to formaldehyde people (2).

\section{Skin sensitizing action}

Formaldehyde is a common cause of contact allergy. Formaldehyde or formaldehyde-releasers (agents that release formaldehyde under usage conditions) may be found in many cosmetics, toiletries, household products such as washing and cleaning agents and in a great number of industrial applications including adhesives, paints, lacquers and metalworking fluids. Skin contact is the most important route of exposure for sensitization $(23,33,47,60,67,69,84)$.

In Europe, $2-3 \%$ of patients suspected of contact dermatitis have positive patch test reactions, and in the USA prevalence rates of sensitization of $8-9 \%$ are reported in this selected group of patients $(23,56)$. A possible explanation of data above is the fact that exposure to formaldehyde in the EU is subject to restrictions. The maximum allowed concentration in finished products is $0.2 \%$ (Annex VI of Cosmetics Directive 76/768/EC).

Dose-response studies aiming patch test standardization indicate that skin allergic reactions in formaldehyde concentration below $0.025-0.05 \%$ are rare (61).

Skin contact occurs in a variety of workplaces. Occupational allergic contact dermatitis is seen among workers from many different industrial branches. Numerous studies report appearance of occupational allergic contact dermatitis from urea-formaldehyde, melamine-formaldehyde, phenol-formaldehyde resin-2 in medium-density fiberboard (MDF) (9, 29, 32, 65).

According to Kie-SwierczyDska (1993) the most important products causing occupational allergic contact dermatitis are disinfectants, coolants and cutting oils, textile finishers and plastics (46).
Numerous studies report about cases of occupational contact dermatitis among machinists working in the fabrication of metal products and exposed to formaldehydecontaining metalworking fluids. Suuronen K. et al. (2007) analyzed data from the Finnish Register of Occupational Diseases during 1992-2001 and calculated incidence rates for skin and respiratory diseases of machinists compared to the total working population. Skin diseases accounted for $27 \%$ of all occupational diseases, while the incidence of respiratory diseases was lower. Authors calculated a 3-fold risk for getting an occupational skin disease for this group of workers compared to the total working population. The number of allergic contact dermatitis increased 3-fold during the study period. The most common causes of allergic contact dermatitis were metalworking fluids and their ingredients such as formaldehyde, ethanolamines and colophony (76).

Geier J. et al. (2006) performed patch testing to investigate sensitization to 10 frequently used metalworking fluids components in 144 metalworkers with suspected occupational dermatitis due to metalworking D;C840. Seven patients reacted positively to the formaldehyde releaser 4,4 'methylenebis morpholine, and 6 of these patients also reacted to formaldehyde and/or other formaldehyde releasers (38).

Aalto-Korte K. et al. (2008) screened the patch test files for allergic reactions to formaldehyde and 12 formaldehyde-releasing compounds for the period of time between January 2001 and May 2007 and reviewed the records of all patients with contact allergy to any of the substances. The authors had patch- tested 81 patients with formaldehyde allergy and 18 with independent allergy to some formaldehyde releaser. Of the formaldehyde allergies, 25 were considered to be occupational. According to the authors, occupational formaldehyde allergy was common and occurred in metalworkers, hairdressers, masseurs, and workers using protective creams, detergents, and liquid soaps. The most common source of occupational sensitization was metalworking fluids followed by creams and related products. Exposure to formaldehyde-releasing preservatives in liquid soaps and other rinse-off products was common in both occupational and non-occupational cases. Reactions to formaldehyde-releasing compounds were seen in $79 \%$ of the formaldehyde-allergic patients. When compared with studies on general dermatological patients, contact allergy to formaldehyde releasers without formaldehyde allergy was rare. $(4,5)$.

The importance of formaldehyde and formaldehyde releasers as occupation-associated allergens in the cleaning industry was shown in a recent study of Liskowsky J. et al. (2011). The authors analysed the patch test data concerning 803 female cleaners, who were evaluated for occupational contact dermatitis from 1996 to 2009. The authors concluded that formaldehyde and rubber additives are occupationally relevant allergens in female cleaners. Prevention strategies are needed to address the problem (57). 
Cases of occupational allergic contact dermatitis from formaldehyde textile finish resins were described $(19,34,69)$. Cases of non-occupational allergic contact dermatitis caused by formaldehyde-releasers in clothes - durable press chemical finishes, were also reported $(23,62,75)$.

Studies report cases of occupational contact dermatitis from colophony and formaldehyde in banknote paper (53), of allergic contact dermatitis from formaldehyde and quaternium-15 in photocopier toner (85), of ccupational dermatitis due to formaldehyde in newspaper (72), of melamine-formaldehyde contact dermatitis in orthopaedic practice (70), and occupational contact dermatitis among funeral service workers and farmers, exposed to formaldehyde $(42,50)$.

Our previous study also described cases of occupational contact dermatitis from formaldehyde among workers in plywood industry and medical personnel who use formaldehyde in pathology laboratories and morgues (1).

Takahashi S. et al. (2007) performed a prospective study of clinical symptoms and skin test reactions in medical students exposed to formaldehyde gas during a human anatomy laboratory course. At the end of the anatomy course $3.3 \%$ of the students tested by patch test became positive to $1 \%$ formaldehyde (77).

Contact dermatitis from formaldehyde among healthcare professionals

Formaldehyde has been found numerous applications in medical science and practice, no matter the reduction of its use in disinfection procedures by other chemical substances from the group of aldehydes - glutaraldehyde and glyoxal).

Schnuch A. et al (1998) analyzed the sensitization pattern and patch-test results of more than 30000 healthcare workers in difficult occupations (nurses, dental nurses, dental technicians, dentists, physicians, masseurs etc. Significantly increased sensitization rates common to the healthcare sector as a whole were found for the vaccine preservative thiomersal, as well as for glutaraldehyde, formaldehyde and glyoxal. The list of different occupations at risk for occupational skin diseases in healthcare sector includes mainly nurses, physicians, masseurs, dental technicians. A significantly increased risk for occupational contact sensitization from glutaraldehyde and glyoxal among nurses was reported (73). In this aspect of practical importance is to evaluate appearance of concomitant sensitization to glutardialdehyde and formaldehyde, respectively (54). In a 5-year study at the University of Kansas, 468 patients were patch tested to glutaraldehyde. A higher than expected co-reactivity between glutaraldehyde and formaldehyde was noted among healthcare workers, which cannot fully be explained by concomitant exposure (74).

Kie-SwierczyDska M. et al. (1998) examined the incidence of allergy to aldehydes (formaldehyde, glutaraldehyde, glyoxal) was in 280 health care workers suffering from skin lesions. Allergic contact dermatitis was diagnosed in $22.8 \%$ of patients, the majority of them (85.9\%) being sensitive only to 1 aldehyde. Formaldehyde caused allergy slightly more frequently $(13.9 \%)$ than glutaraldehyde $(12.4 \%)$. Only $1.9 \%$ of patients were sensitive to glyoxal. The authors confirmed the sensitizing activity of aldehydes also in guinea pigs. Formaldehyde showed the strongest and most persistent reactions. Significantly higher eosinophil and basophil counts were found in the blood samples of the sensitized guinea pigs (49). These results were also confirmed in a subsequent study (48), when the authors examined 223 nurses because of suspected occupational dermatoses. The diagnosis contact allergy was based on the positive results of patch tests, and immediate allergy to common allergens and latex on the results of prick tests, as well as on the determinations of specific IgE antibodies. Contact allergy was diagnosed in $66.4 \%$ of nurses. Sensitization to formaldehyde was diagnosed in $20.6 \%$ of patients, to glutaraldehyde - in $10.8 \%$,

The authors concluded that the contact with disinfectants was causative for occupational skin sensitization of $40.8 \%$ of allergic nurses,

In another paper the same authors (Kie-SwierczyDska M., Krecisz B. - 2000) performed an analysis about the causes of occupational allergy in dental nurses based on the summarization of data for a period 4 years. Contact sensitisation (at least one positive epidermal test) was found in $66.7 \%$ of the examined nurses. Among the aldehydes, occupational allergic dermatitis was induced induced most frequently by glutaraldehyde ( 7 positive patch tests), formaldehyde (4), and glyoxal (3). The present components of disinfectants (aldehydes) are the major etiologic agents that induce occupational allergy (45).

Gawkrodger D.J. (2005) included formaldehyde in the list of agents, causing most often contact allergy in dental staff. According to the author occupational irritant problems causing hand dermatitis are probably more common in dental personnel than is dermatitis caused by contact allergy (36).

Ravis S. M. et al. (2003) performed patch-testing to investigate the incidence of glutaraldehyde-induced and formaldehyde-induced allergic contact dermatitis among 101 dental hygienists and assistants (68). The obtained results are in contrast with previous findings - no significantly increased incidence of occupational sensitization from formaldehyde was found in dental personnel (significantly higher was the incidence of sensitization from glutaraldehyde). No co-reactivity between glutaraldehyde and formaldehyde was established.

Sensitizing action of formaldehyde as an ingredient in dental materials

No matter the trend for limitations formaldehyde is still used in dental practice - as an ingredient in dental 
materials, especially root-canal-filling materials used in contemporary endodontic therapy. Hauman C. H. J. 8 Love R. M. (2003) in a review paper describe the content and biocompatibility of root-canal-filling materials. A large group of sealer/cements, including the commonly used Endomethasone, Riebler's paste, N2, AH26, several composite resins, etc. contain substantial amounts of paraformaldehyde and are able to liberate formaldehyde into water in amounts sufficient to cause local allergic reactions (39).

Cohen et al. (1998), Koch $(1997,1999)$ evaluated the release of formaldehyde from some endodontic materials root canal filling sealers, and demonstrated that all materials showed the highest release of formaldehyde in the freshly mixed samples. The release of formaldehyde decreased after setting for $48 \mathrm{~h}$. No further decrease was seen after storage for 2 weeks in the case of N2, while AH26 released only insignificant amounts after 2 weeks $(20,52,53)$.

Intriguing data are available concerning allergic reactions to formaldehyde in a dental root canal compound, during and after endodontic treatment. Cases of contact urticaria from formaldehyde in a root-canal dental paste $\mathbf{( 2 8}$, 30), as well as cases of anaphylactic reactions to formaldehyde in root canal sealant (four cases of anaphylactic shock and three of generalized urticaria, with positive skin tests and high levels of anti-formaldehyde IgE) were described $(13,14)$.

According to Tas E. et al. (2002), in the literature 28 patients with immediate symptoms to formaldehyde containing root canal compounds have been described. The authors presented a patient who had suffered twice from an acute urticaria after treatment with two different dental root canal compounds (RCC). Skin prick tests with the single components and formaldehyde $1 \%$ aq. were positive to formaldehyde 1\%aq., but irritant with formaldehyde RCC. Specific IgE to formaldehyde were positive. Patch tests were positive to formaldehyde RCC only (80).

In a recent study Kijima A. et al. (2007) reported two cases of generalized urticaria after the dental treatment. The authors diagnosed them as type I allergy due to formaldehyde - these cases had clearly positive RAST to formaldehyde, whereas skin prick testings were negative. Also, previous reports of immediate allergy to formaldehyde in dental treatment were reviewed and its characteristics were summarized. First, it tends to represent severe symptom like anaphylaxis, second, the symptom often appears a few hours later than usual cases of anaphylaxis. Allergen tests show highly positive ratio to formaldehyde RAST, whereas skin prick test often shows false negative. The conclusion of the author is that assessment of specific $\operatorname{IgE}$ to formaldehyde is a useful and a diagnostic measurement, and is recommended in patients at risk (51).

\section{Carcinogenity}

In 2004 the international agency for research on cancer (IARC) classified formaldehyde as carcinogenic to humans (group 1), based on sufficient evidence in humans and sufficient evidence in experimental animals. Based on the information available, this classification is higher than those of previous IARC evaluations (IARC 1982, 1987, 1995) (44). On June 10, 2011 U.S. Department of Health and Human Services released the $12^{\text {th }}$ Report on Carcinogens. The listing status of formaldehyde was changed to known to be a human carcinogen (63). The criterion for listing as known to be a human carcinogen is "sufficient evidence of carcinogenicity from studies in humans, which indicates a causal relationship between exposure to the agent, substance, or mixture, and human cancer". Studies in humans have shown that formaldehyde causes nasopharyngeal cancer, sinonasal cancer, and myeloid leukemia (63).

Summarization of the toxic, immunotoxic and sensitizing effects associated with exposure to formaldehyde in both residential and occupational settings

1. The most common effect includes irritation at the point of contact upper respiratory tract and eyes, (mouth and gastrointestinal tract, skin and eyes.

2. Due to the specificity of the metabolism of formaldehyde most of all the direct effects occur at the point of entry in the upper respiratory tract. Immune cells in the bronchial and nasal associated lymphoid tissue (BALT and NALT) are most likely proximal targets of formaldehyde. Adverse effects of formaldehyde on BALT and NALT may be manifested systemically because these cells migrate to the lymph nodes, spleen, liver, peripheral blood, and other immune tissues.

3. The most common effects on the upper respiratory tract mucosa are inflammation, rhinitis, altered mucociliary action, hyperplasia, squamous metaplasia, and mild dysplasia; formaldehyde affects multiple gene expression pathways, including those involved in DNA synthesis and repair, regulation of cell proliferation, and apoptosis.

4. Formaldehyde exposure is associated with lung function decrements peak expiratory flow and forced expiratory volume in 1 second) and bronchial hyper reactivity.

5. Inhalation exposure to formaldehyde has also been identified as a potential cause of asthma or asthma-like symptoms, especially in children.

6. Formaldehyde is a primary skin sensitizing agent and has been associated with both contact dermatitis (Type IV allergy), and immediate, anaphylactic reactions (Type I allergy). Inhalation exposure could contribute foe manifestation of allergic contact dermatitis. Co-reactivity between glutaraldehyde and formaldehyde was reported, which cannot fully be explained by concomitant exposure

7. Formaldehyde-specific IgE antibodies were detected in some studies, but their presence is transitional, 
and a $\mathrm{T}$ helper type 2-skewed immune response was not promoted.

\section{CONCLUSION}

Formaldehyde is a ubiquitous chemical agent of our general outdoor environment, as well as in our indoor working and residential environment. Healthcare workers in difficult occupations are among the most affected by formaldehyde exposure. Quite a few investigations are available concerning health issues for dental students following formaldehyde exposure during the course of education. Such kind of studies would be beneficial for early diagnosis of hypersensitivity, adequate prophylactic, risk assessment and management of their work in the specific dental workshop occupational environment. Also, this would for provide a better medical and social-economical prognosis for future dentists.

\section{REFERENCES:}

1. M. Nosko, E. Petrova, M. Lyapin, N. Madjunov, T. Panev, B. Dragova, St. Lalchev. Occupational risk in formaldehyde exposure. Problems of Hygiene. 2000, XXI, No1, 16-21. [in Bulgarian]

2. M. Nosko, E. Petrova, M. Lyapin, B. Dragova, M. Boev, J. Pomakov, G. Zelezova. Toxic actions of occupational formaldehyde exposure. Hygiene and Public Health. 2001 2-3, 40-44. [in Bulgarian]

3. M. Nosko, E. Petrova, M. Lyapin, D. Baltadjieva, N. Madjunov, Chr. Christov, M. Stoynovska. Investigation of some aspects of the immunotoxic action of formaldehyde. Hygiene and Public Health. 1999, 2, 16-18. [in Bulgarian]

4. Aalto-Korte K, Kuuliala O, Suuronen K, Alamko K. Occupational contact allergy to formaldehyde and formaldehyde releasers. Contact Dermatitis. 2008 Nov; 59(5):280-9. [PubMed] [CrossRef]

5. Aalto-Korte K, Makela EA, Huttunen M, Suuronen K, Jolanki R. Occupational contact allergy to glyoxal. Contact Dermatitis. 2005 May;52(5):276-81. [PubMed] [CrossRef]

6. Andersen I., Mwlhave L. (1983) Controlled human studies with formaldehyde. In: Gibson, JE; ed. Formaldehyde toxicity. Washington, DC: Hemisphere Publishing Corporation; pp. 154-165

7. Ballarin C, Sarto F, Giacomelli L. Bartolucci GB, Clonfero E. Micronucleated cells in nasal mucosa of formaldehydeexposed workers. Mutat Res. 1992 Jul;280(1):1-7. [PubMed]

8. Bateson T.F., Schwartz J. Children's response to air pollutants. $J$ Toxicol Environ Health A. 2008, 71(3):238-243. [PubMed] [CrossRef]

9. Bell HK, King CM. Allergic contact dermatitis from urea-formaldehyde resin in medium-density fibreboard (MDF). Contact Dermatitis. 2002 Apr;46(4):247. [PubMed] [CrossRef]
10. Bernstein RS, Stayner LT, Elliott LJ. Kimbrough R, Falk H, Blade L. Inhalation exposure to formaldehyde: an overview of its toxicology, epidemiology, monitoring, and control. Am Ind Hyg Assoc J. 1984 Nov; 45(11):778-85. [PubMed]

11. Bostrom CE, Almen J, Steen B. Westerholm R. Human exposure to urban air pollution. Environ Health Perspect. 1994 Oct;102, Soppl 4:39-47. [PubMed]

12. Boysen M, Zadig E, Digernes V, Abeler V, Reith A. Nasal mucosa in workers exposed to formaldehyde: a pilot study. $\mathrm{Br}$ $J$ Ind Med. 1990 Feb;47(2):116-121. [PubMed]

13. Braun JJ, Valfrey J, Scherer P, Zana H, Haikel Y, Pauli G. IgE allergy due to formaldehyde paste during endodontic treatment. Apropos of 4 cases: 2 with anaphylactic shock and 2 with generalized urticaria. Rev Stomatol Chir Maxillofac. 2000 Oct;101(4):169-74. [Article in French] [PubMed]

14. Braun JJ, Zana H, Purohit A, Valfrey J, Scherer P, Hankel Y, et al. (2003) Anaphylactic reactions to formaldehyde in root canal sealant after endodontic treatment: four cases of anaphylactic shock and three of generalized urticaria. Allergy. 2003 Nov;58(11):1210-5. [PubMed]

15. Broder I, Corey P, Brasher P, Lipa M, Cole P. Formaldehyde exposure and health status in households. Environ Health Perspect. 1991 Nov;95:101-104. [PubMed]

16. Casanova M, Heck HD, Everitt JI, Harrington WW Jr, Popp JA. Formaldehyde concentrations in the blood of rhesus monkeys after inhalation exposure. Food Chem Toxicol. 1988 Aug;26(8):715-716. [PubMed]

17. Casset A., Purohit A., Marchand C. Le Calvй S, Donnay C, Uring-Lambert B, et al. The bronchial response to inhaled formaldehyde. Rev Mal Respir. 2006 Feb;23(1 Suppl):3S25-34. [Article in
French] [PubMed]

18. Final Report on Formaldehyde Levels in FEMA-Supplied Travel Trailers, Park Models and Mobile Homes. Centers for Disease Control and Prevention (U.S.). CDC (2008)

19. Cockayne SE, McDonagh AJ, Gawkrodger DJ. Occupational allergic contact dermatitis from formaldehyde resin in clothing. Contact Dermatitis. 2001 Feb;44(2):109-110. [PubMed] [CrossRef]

20. Cohen BI, Pagnillo MK, Musikant BL, Deutsch AS. Evaluationof the release of formaldehyde for three endodontic filling materials. Oral Health. 1998 Dec;88(12): 37-9. [PubMed]

20. Costantini C, Cassatella M. Crosstalks between neutrophils and NK cells. $J$ Leukoc Biol. 2011 Feb;89(2):221-233. [PubMed]

21. Crump DR. 1995. Volatile organic compounds in indoor air. In: Hester RE, Harrison RM, ed. Volatile organic compounds in the atmosphere. Issues in environmental science and technology 4th ed. Cambridge: Royal Society of Chemistry, 109-124.

22. Dally KA, Hanrahan LP, Woodbury MA, Kanarek MS. Formaldehyde exposure in nonoccupational environments. Arch Environ Health. 1981 Nov-Dec;36(6):277284. [PubMed]

23. De Groot AC, Le Coz CJ, Lensen GJ, Flyvholm MA, Maibach HI, Coenraads PJ. Formaldehyde-releasers: relationship to formaldehyde contact allergy. Part 2. Formaldehyde-releasers in clothes: durable press chemical finishes. Contact Dermatitis. 2010 Jul;63(1):1-9. [PubMed] [CrossRef]

24. Delfino RJ. Epidemiologic evidence for asthma and exposure to air toxics: linkages between occupational, indoor, and community air pollution research. Environ Health Perspect. 2002 Aug;110 Suppl 4:573-589. [PubMed] 
25. Delfino RJ, Gong H Jr, Linn WS, Pellizzari ED, Hu Y. (2003) Asthma symptoms in Hispanic children and daily ambient exposures to toxic and criteria air pollutants. Environ Health Perspect. 2003 Apr;111(4):647-656. [PubMed]

26. Doi S, Suzuki S, Morishita M, Yamada M, Kanda Y, Torii S, et al. The prevalence of IgE sensitization to formaldehyde in asthmatic children. Allergy. 2003 Jul;58(7):668-671. [PubMed] [CrossRef]

27. Doty RL, Cometto-Muniz JE, Jalowayski AA, Dalton P, Kendal-Reed M, Hodgson M. Assessment of upper respiratory tract and ocular irritative effects of volatile chemicals in humans. Crit Rev Toxicol. 2004 Mar-Apr;34(2):85-142. [PubMed]

28. el Sayed F, Seite-Bellezza D, Sans B, Bayle-Lebey P, Marguery MC, Bazex J. (1995) Contact urticaria from formaldehyde in a root-canal dental paste. Contact Dermatitis. 1995 Nov;33(5):353. [PubMed]

29. Ezughah FI, Murdoch SR, Finch TM. Occupational airborne allergic contact dermatitis from medium-density fibreboard containing phenol-formaldehyde resin-2 (PFR-2). Contact Dermatitis. 2001 Oct;45(4):242. [PubMed] [CrossRef]

30. Fehr B, Huwyler T, Wuthrich B. Formaldehyde and paraformaldehyde allergy. Allergic reactions to formaldehyde and paraformaldehyde after tooth root treatments. [Article in French, German] Schweiz Monatsschr Zahnmed. 1992 102(1):94-7. [PubMed]

31. Feron VJ. Til HP, de Vrijer F, Woutersen RA, Cassee FR, van Bladeren PJ. Aldehydes: occurrence, carcinogenic potential mechanism of action and risk assessment. Mutat Res. 1991 MarApr;259(3-4):363-385. [PubMed]

32. Finch TM, Prais L, Foulds IS. Allergic contact dermatitis from mediumdensity fibreboard containing melamineformaldehyde resin. Contact Dermatitis. 1999 Nov;41(5):291. [PubMed]

33. Flyvholm MA. Contact allergens in registered chemical products. Contact Dermatitis. 1991 Jul;25(1):49-56. [PubMed]

34. Garcна Bracamonte B, Ortiz de Frutos FJ, Iglesias Diez L. Occupational allergic contact dermatitis due to formaldehyde and textile finish resins. Contact Dermatitis. 1995 Aug;33(2):139-40. [PubMed]

35. Garcia JP, Beyne-Masclet S, Mouvier G. Emissions of volatile organic compounds by coal-fired power stations. Atmos Environ. 1992; 26A(9):1589-1597.
36. Gawkrodger DJ. Investigation of reactions to dental materials. $\mathrm{Br} J$ Dermatol. 2005 Sep;153(3):479-85. [PubMed] [CrossRef]

37. Garry VF, Oatman L, Pleus R. Gray D. Formaldehyde in the home: Some environmental disease perspectives. Minn Med. 1980 Feb;63(2):107-111. [PubMed]

38. Geier J, Lessmann H, Becker D, Bruze M, Frosch PJ, Fuchs T, et al. Patch testing with components of water-based metalworking fluids: results of a multicentre study with a second series. Contact Dermatitis. 2006 Dec;55(6):322-9. [PubMed] [CrossRef]

39. Hauman $\mathrm{CH}$, Love RM. Biocompatibility of dental materials used in contemporary endodontic therapy: a review. Part 2. Root-canal-filling materials. Int Endod J. 2003 Mar;36(3):147-160. [PubMed] [CrossRef]

40. Heck HD, Casanova-Schmitz M, Dodd PB, Schachter EN, Witek TJ, Tosun T. Formaldehyde (CH2O) concentrations in the blood of humans and Fischer-344 rats exposed to $\mathrm{CH} 2 \mathrm{O}$ under controlled conditions. Am Ind Hyg Assoc J. 1985 Jan;46(1):1-3. [PubMed]

41. Holmstrom M, Wilhelmsson B. Respiratory symptoms and pathophysiological effects of occupational exposure to formaldehyde and wood dust. Scand J Work Environ Health. 1988 Oct;14(5):306-311. [PubMed] [CrossRef]

42. Holness DL, Nethercott JR. Health status of funeral service workers exposed to formaldehyde. Arch Environ Health 1989 Jul-Aug;44(4):222-8. [PubMed]

43. HSDB. 2009. Hazardous Substances Data Bank. National Library of Medicine. http://toxnet.nlm.nih.gov/cgi-bin/sis/ htmlgen?HSDB and search on CAS number. Last accessed: 6/2/09.

44. IARC. (2006) Formaldehyde. In IARC Monographs on the Evaluation of Carcinogenic Risks to Humans. Formaldehyde, 2-Butoxyethanol and 1-tertButoxypropan-2-ol, vol. 88, Lyon, France: International Agency for Research on Cancer. pp. 39-325

45. Kiec-Swierczynska M, Krecisz B. Causes of occupational allergy in dental nurses. An analysis based on the material collected at The Institute of Occupational Medicine in Lydz. Med Pr. 2000, 51(2):1459. [Article in Polish] [PubMed]

46. Kiec-Swierczynska M. Contact allergy caused by formaldehyde, based on materials from the Institute for medical occupations in Lodz. Med Pr.1993,
44(3):209-13. [Article in Polish] [PubMed]

47. Kiec-Swierczynska M. Occupational allergic contact dermatitis in Lodz: 19901994. OccupMed (Lond). 1996, Jun;46(3): 205-208. [PubMed]

48. Kiec-Swierczynska M, Krecisz B. Occupational skin diseases among the nurses in the region of Lydz. Int J Occup Med Environ Health. 2000, 13(3):179-84. [PubMed]

49. Kiec-Swierczynska M, Krecisz B, Krysiak B. Kuchowicz E, Rydzynski K. Occupational allergy to aldehydes in health care workers. Clinical observations. Experiments. Int J Occup Med Environ Health. 1998; 11(4):349-58. [PubMed]

50. Kiec-Swierczynska M, Krecisz B, Swierczynska-Machura D. Most frequent causes of allergic contact dermatitis in farmers: based on material collected in the Nofer Institute of Occupational Medicine, Lodz. [Article in Polish] Med Pr. 2003; 54(3):237-43. [PubMed]

51. Kijima A, Nishino H, Umeda J, Kataoka Y. Type 1 allergy to formaldehyde in root canal sealant after dental treatment: two case reports and review of the literature. [Article in Japanese] Arerugi. 2007 Nov;56(11):1397-402. [PubMed]

52. Koch MJ. Formaldehyde release from root-canal sealers: influence of method. Int Endod J. 1999 Jan;32(1):10-6. [PubMed] [CrossRef]

53. Koch P. Occupational contact dermatitis from colophony and formaldehyde in banknote paper. Contact Dermatitis. 1995 Jun;32(6):371-372. [PubMed]

54. Krecisz B, Kiec-Swierczynska M. The role of formaldehyde in the occurrence of contact allergy. [Article in Polish] Med Pr. 1998 49(6):609-14. [PubMed]

55. Krzyzanowski M, Quackenboss JJ, Lebowitz MD. Chronic respiratory effects of indoor formaldehyde exposure. Environ Res. 1990 Aug;52(2):117-125. [PubMed]

56. Lang I, Bruckner T, Triebig G. Formaldehyde and chemosensory irritation in humans: A controlled human exposure study. Regul Toxicol Pharmacol. 2008 Feb;50(1):23-36. [PubMed] [CrossRef]

57. Liskowsky J, Geier J, Bauer A. Contact allergy in the cleaning industry: analysis of contact allergy surveillance data of the Information Network of Departments of Dermatology. Contact Dermatitis. 2011 Sep;65(3):159-166. [PubMed] [CrossRef]

58. Liu KS, Huang FY, Hayward SB, Wesolowski J, Sexton K. Irritant effects of formaldehyde exposure in mobile homes. Environ Health Perspect. 1991 Aug;94:91- 
94. [PubMed]

59. Lyapina M, Zhelezova G, Petrova E, Boev M. Flow cytometric determination of neutrophil respiratory burst activity in workers exposed to formaldehyde. Int Arch Occup Environ Health. 2004 Jun;77(5):335340. Epub 2004 May 1. [PubMed] [CrossRef]

60. Maibach H. Formaldehyde: effects on animal and human skin. In: Gibson J.E., ed. Formaldehyde toxicity. Washington, DC: Hemisphere Publishing Corporation. 1983 166-174.

61. Marks JGJ, Belsito DV, DeLeo VA. et al. (1995) North American contact dermatitis group standard tray patch test results (1992 to 1994). Am J Contact Dermatitis 6:160-165

62. Nedorost S, Warshaw E, Jacob S, Katta R, Zirwas M, Andrew S. Allergic contact dermatitis caused by durable-press finishes does exist in the USA. Contact Dermatitis. 2010 Oct;63(4):233-4. [PubMed] [CrossRef]

63. NTP (2010) Report on Carcinogens Background Document for Formaldehyde. National Toxicology Program. http:// ntp.niehs.nih.gov/ntp/roc/twelfth/2009/ November/Formaldehyde_BD_Final.pdf .

64. Ohmichi K, Komiyama M, Matsuno Y, Sawabe Y, Miyaso H, Fukata H, et al. Relationship between exposure to formaldehyde and immunoglobulin E ( $\operatorname{IgE}$ ) production during the gross anatomy laboratory. J Health Sci. 2006; 52(5):642647.

65. Owen CM, Beck MH. Occupational allergic contact dermatitis from phenolformaldehyde resins. Contact Dermatitis. 2001 Nov;45(5):294-295. [PubMed] [CrossRef]

66. Pazdrak K, Gyrski P, Krakowiak A, Ruta U. Changes in nasal lavage fluid due to formaldehyde inhalation. Int Arch Occup Environ Health. 1993; 64(7):515-519. [PubMed]

67. Rastogi SC. A survey of formaldehyde in shampoos and skin creams on the Danish market. Contact Dermatitis. 1992 Oct;27(4):235-240. [PubMed]

68. Ravis SM, Shaffer MP, Shaffer CL, Dehkhaghani S, Belsito DV. Glutaraldehyde-induced and formaldehyde-induced allergic contact dermatitis among dental hygienists and assistants. J Am Dent Assoc. 2003 Aug;134(8):1072-1078. [PubMed]

69. Reich HC, Warshaw EM. Allergic contact dermatitis from formaldehyde textile resins. Dermatitis. 2010 Apr;21(2):65-76. [PubMed]

70. Ross JS, Rycroft RJ, Cronin E. Melamine-formaldehyde contact dermatitis in orthopaedic practice. Contact Dermatitis. 1992 Mar;26(3):203-204. [PubMed]

71. Salthammer T, Mentese S, Marutzky R. Formaldehyde in the Indoor Environment. Chem Rev. 2010 Apr 14; 110(4):2536-2572. [PubMed] [CrossRef]

72. Sanchez I, Rodriguez F, Quicones D, Garcia-Abujeta JL, Fernandez L, MartinGil D. Occupational dermatitis due to formaldehyde in newspaper. Contact Dermatitis. 1997 Sep;37(3):131-132. [PubMed]

73. Schnuch A, Uter W, Geier J, Frosch PJ, Rustemeyer T. Contact allergies in healthcare workers. Results from the IVDK. Acta Derm Venerol. 1998 Sep;78(5):358363. [PubMed]

74. Shaffer MP, Belsito DV. Allergic contact dermatitis from glutaraldehyde in health-care workers. Contact Dermatitis. 2000 Sep;43(3);150-6. [PubMed] [CrossRef]

75. Slodownik D, Williams J, Tate B, Tam M, Cahill J, Frowen K, et al. Textile allergy - the Melbourne experience. Contact Dermatitis. 2011 Jul;65(1):38-42. [PubMed] [CrossRef]

76. Suuronen K, Aalto-Korte K, Piipari R, Tuomi T, Jolanki R. Occupational dermatitis and allergic respiratory diseases in Finnish metalworking machinists. Occup Med (Lond). 2007 Jun;57(4):277-83. [PubMed] [CrossRef]
77. Takahashi S, Tsuji K, Fujii K, Okazaki F, Takigawa T, Ohtsuka A, et al. Prospective study of clinical symptoms and skin test reactions in medical students exposed to formaldehyde gas. J Dermatol. 2007 May;34(5):283-289. [PubMed] [CrossRef]

78. Takigawa T, Usami M, Yamasaki Y, Wang B, Sakano N, Horike T, et al. Reduction of indoor formaldehyde concentrations and subjective symptoms in a gross anatomy laboratory. Bull Environ Contam Toxicol. 2005 Jun;74(6):1027-1033. [PubMed]

79. Tang X, Bai Y, Duong A, Smith MT, Li L, Zhang L. Formaldehyde in China: Production, consumption, exposure levels, and health effects. Environ Int. 2009 Nov; 35(8):1210-1224. [PubMed] [CrossRef]

80. Tas E, Pletscher M, Bircher AJ. IgEmediated urticaria from formaldehyde in a dental root canal compound. J Investig Allergol Clin Immunol. 2002; 12(2):130-3. [PubMed]

81. U.S. Department of Health and Human Services, Public Health Service, National Toxicology Program. (2011) Report on Carcinogens, Twelfth Edition; http://ntp.niehs.nih.gov/ntp/roc/twelfth/ roc12.pdf

82. White JML, White IR, de Groot AC. Cosmetics and Skin Care Products. Contact Dermatitis, 2011; 6, 591-605. [CrossRef]

83. WHO (2002) Formaldehyde: Concise International Chemical Assessment Document World Health Organization. Geneva. http://www.inchem.org/documents/ cicads/cicads/cicad40.htm

84. Wilhelmsson B, Holmstrцm M. Possible mechanisms of formaldehydeinduced discomfort in the upper airways. Scand J Work Environ Health. 1992 Dec; 18(6):403-407. [PubMed] [CrossRef]

85. Zina AM, Fanan E, Bundino S. Allergic contact dermatitis from formaldehyde and quaternium-15 in photocopier toner. Contact Dermatitis. 2000 Oct;43(4): 241-2. [PubMed]

\section{Corresponding author:}

Dr. Maya Lyapina,

Department Hygiene, medical ecology and nutrition, Medical Faculty, Medical University, Sofia, Bulgaria

15, Acad. Ivan Geshov blvd., 1431 Sofia, Bulgaria

Mob.: +359/887 161768

e-mail: saly_grigory@abv.bg; 